\title{
Management Learning in Historical Perspective: Rediscovering Rowntree and the British Interwar Management Movement
}

\author{
Mairi Maclean \\ University of Bath, UK \\ kmm57@bath.ac.uk \\ Gareth Shaw \\ University of Exeter, UK \\ G.Shaw@exeter.ac.uk \\ Charles Harvey \\ Newcastle University, UK \\ Charles.Harvey@ncl.ac.uk
}

\author{
Alan Booth \\ University of Exeter, UK \\ a.e.booth@exeter.ac.uk
}

To be published as: Maclean, M., Shaw, G., Harvey, C. \& Booth, A. (2019). Management Learning in Historical Perspective: Rediscovering Rowntree and the British Interwar Management Movement. Academy of Management Learning \& Education, forthcoming.

Corresponding author: Professor Mairi Maclean, School of Management, 8 West 4.19, University of Bath, Claverton Down, Bath, BA2 7AY, UK.

Email: kmm57@bath.ac.uk

\section{Acknowledgement}

The authors would like to thank Editor-in-Chief Bill Foster and Associate Editor Gabrielle Durepos for their support and expert guidance throughout the review process. We would like to thank the three anonymous $A M L E$ reviewers for their many valuable recommendations that have greatly strengthened our paper. Our paper benefitted from discussions at the Association of Business Historians annual conference (2018) held at the Open University, Milton Keynes, and at the British Academy of Management (BAM) annual conference (2018) held at the University of the West of England, Bristol, where it won the best paper award of the Management and Business History Division. We wish to thank Rachel Pistol, Morgen Witzel and Johannah Duffy for research assistance. The construction of our online repository would not have been possible without contributions by Heather Makin, Paul Cleave, Julia Hopkin and Fujia Li together with Gary Stringer and Richard Holding from the Digital Humanities Lab, University of Exeter. We are very grateful for the support throughout the project of archivists Sophie Clapp (Boots), Tim Crumplin (Alfred Gillet Trust), Sally-Anne Shearn (Borthwick), Anna Towlson (LSE), and Claire Tunstall (Unilever). Finally, we would like to express our thanks to the Economic and Social Research Council (ESRC) for kindly supporting the research on which this article is based (Grant Ref. ES/N009797/1). 


\section{ABSTRACT}

British interwar management (1918-1939) has been criticized as overly conservative, comprising a core of progressive firms amidst a mass of conservatively-run, familydominated businesses. According to the dominant narrative, British firms exhibited little interest in new managerial approaches. Our study of the Rowntree business lectures and British interwar management movement challenges this view; suggesting British managers displayed greater openness to innovation than is commonly recognized. We uncover and analyse a network of British firms engaged in management education through organized peerto-peer communication, facilitated by lectures and management research groups initiated by Seebohm Rowntree. Our primary contribution to the literature is to offer a more nuanced perspective on the evolution of British management learning in the interwar years. This reveals dynamic knowledge networks reflexively engaged in advancing and codifying practice-based learning to promote the diffusion of effective solutions to shared problems building communities of practice, codifying management knowledge, and drawing on an ethos of 'business as service'. By undertaking archival research to create a coherent body of documentary material, and making this available to others, we also make a methodological contribution, creating a new 'space' for future researchers to explore, from which they can write new management histories of their own.

KEYWORDS: Communities of practice; Knowledge transfer; Management education; Management history; Management knowledge; Management learning.

\section{INTRODUCTION}

British interwar management has been criticized as unduly conservative, consisting of a small nucleus of progressive firms amidst a mass of conservatively-run, family-dominated enterprises (Hannah, 1983). According to the dominant narrative, British business culture between the wars (1918-1939) was held in the grip of tradition, blinded by practical 
empiricism and weighed down by past practice (Wilson, 1995; Wilson \& Thomson, 2006). British firms are considered to have displayed little interest in novel managerial methods, skills and techniques, especially beneath an elite of well-managed firms, in contrast to the Chandlerian-inspired vision of the giant, multi-divisional corporation in the United States (U.S.) (Chandler, 1990). Keeble (1992: 1) presents British management as slow to embrace change, reluctant to make investments in management, manufacturing and marketing capabilities, and led by 'industrial incompetents' with 'low levels of education and training'. The few progressive enterprises that emerged - amongst which British Quaker welfarist employers Rowntree and Cadbury were considered to be at the forefront - are deemed unrepresentative of the many (McIvor, 1987). Yet, despite this disparaging assessment, it is acknowledged that Britain had some leading management thinkers (Sheldon, 1923; Urwick, 1956; Urwick \& Brech, 2002), and that a significant number of firms employed management consultants (Ferguson, 2002; Kipping, 1997; 1999; Kipping \& Engwell, 2003).

In this paper, inspired by recent calls to 'think differently' (Cummings \& Bridgman, 2016; Cummings, Bridgman, Hassard, \& Rowlinson, 2017; McLaren, 2019) to re-examine the foundations of modern management more thoroughly (Bridgman, Cummings, \& Ballard, 2019; Dent \& Bozeman, 2014), we take this pessimistic judgement to task. Encouraged by Cummings and Bridgman's (2011) assertion that 'the primary purpose of embracing management history should be to work against being restricted by what others have regarded as historical conventions', we offer a provisional recalibration and partial corrective to this view by presenting a counter narrative. We explore the major expansion of practice-based learning for managers conducted across a sizeable network of progressive British firms through organized peer-to-peer communication in the interwar period. Our research suggests that British managers displayed greater openness to innovation allied to a greater willingness to confront shared problems than is generally acknowledged. We aim to foster a richer, better 
contextualized, and more engaged appreciation of the history of management learning in Britain between the wars (Cummings \& Bridgman, 2011; 2016). This seeks to redirect attention from the dominant logic of British business as declinist and languishing in a restrictive phase of personal capitalism dominated by conservative family firms (Chandler, 1990). Hannah (2007) suggests that managerial capitalism may have been further advanced in Britain than in the U.S. by World War I, while Scranton (1997) suspects the Chandlerian model applied to a mere handful of the largest U.S. firms before the 1930s. We present a nuanced picture of British management thinking and learning between the wars that repositions business education relative to extant historiography. In this way, we contribute to a better-informed understanding of the evolution of British management learning in the interwar years. This reveals a multi-layered initiative in peer education, practice-based but academically buttressed. Its emphasis was on finding practical solutions to employeridentified issues and bringing new ideas directly to British firms to improve their problemsolving capabilities (Cohen \& Levinthal, 1990).

The British interwar management movement arose from a Quaker business initiative launched during World War I to suggest a viable way forward for British industry at a time of intense labour unrest. Following the end of hostilities, the need for reform appeared even more urgent (O’Connor, 1999). In this context, Quaker employers spearheaded the way with three significant management innovations (Smith, Child, \& Rowlinson, 1990). First, they convened a conference of Quaker employers (the Cadbury conferences) to spark discussions on the emerging post-war industrial and social order (Conference of Quaker Employers, 1918). Second, from this initial meeting, the prominent Quaker industrialist, Benjamin Seebohm Rowntree (1871-1954), who during the war had served at the Ministry of Munitions as Director of its Welfare Department (1915-1918), organized a separate set of meetings. The Rowntree lecture series, as it became known, was designed to bring together employers and 
employees from different levels of the hierarchy, particularly works directors, managers, foremen and forewomen, to debate pressing issues confronting British industry. Third, Seebohm Rowntree returned from his successful visit to the U.S. in 1921 with the germ of an idea for key industrialists to meet to debate, and solve, some of the intractable problems facing them. This gave rise to the first Management Research Groups (MRGs) in 1926-1927. Our aim in this study is to increase awareness of the material deriving from the Rowntree business lectures and the British interwar management movement, creating a 'space' for future researchers to explore, while questioning the received, highly critical view of British managers. To this end, the primary research question we pose in this paper is: to what degree does our research demonstrate a greater openness to management learning, innovation and new ideas and a greater eagerness to share problems on the part of British managers than has been previously recognized? As Cooke and Alcadipani (2015: 483) observe, despite a clear commitment to history, $A M L E$ has not yet showcased much research founded on archival analysis, 'the historian's empirical method of choice'. Despite growing appeals to take history seriously, relatively few management scholars make use of archival sources. There are naturally exceptions to this (e.g. Cooke \& Alcadipani, 2015; Gillett \& Tennent, 2017; Maclean, Harvey, Sillince, \& Golant, 2014; 2018a), some of which we explore below (Bruce, 2006; Hassard, 2012; O’Connor, 1999). However, this provides the present researchers with an opportunity to demonstrate the deeper engagement with archives urged by Cummings and Bridgman (2016), in what has proved to be an intensive, archivalbased study.

Our paper unfolds as follows. The next section reviews recent literature on historicizing organizational research and the new critically reflective management history, before examining the dominant narrative, against which we position our counter narrative. Next, we provide details of the research underpinning our study, clarifying our research 
process, data sources and analytical methods. In our empirical section, we draw on archival material to explore processes of management learning and education among the communities of practice that arose through the interwar management movement. In doing so, we examine the notion of 'business as service' that informed the movement's activities and consider how looking back in time might cast new light on contemporary debates (McLaren, 2019).

\section{RETHINKING THE INTERWAR BRITISH MANAGEMENT MOVEMENT Historicizing Organizational Research}

For over two decades, organization theorists have highlighted the need for more and better research that acknowledges the importance of the past in influencing the present and shaping the future (Kieser, 1994). Some commentators have discerned a distinct historic turn in organization studies, spearheaded by scholars who perceive the field to have been hampered by an inclination towards contemporary studies addressing limited periods of time (Clark \& Rowlinson, 2004). Locating a subject in historical perspective, on the other hand, might elucidate its earliest stages and ensuing development. Historicizing organizational research might enable the contexts and forces bearing upon enterprises to be more fully recognized and analyses of organizational dynamics to be deepened.

These and analogous concerns have been the subject of extensive discussion in recent years, engendering a growing number of publications while pointing to avenues for further exploration (Bucheli \& Wadhwani, 2014; Maclean, Harvey, \& Clegg, 2016; Rowlinson, Decker, \& Hassard, 2014). Commentators have explicated the problems inherent in reconciling history and organization theory, suggesting ways of accommodating differences. Kipping and Üsdiken (2014) propose three types of correspondence: history as a means of testing theory, informing theoretical perspectives, and lending complexity to theorization. Building on these insights, Maclean, Harvey and Clegg $(2016$; 2017) identify five principles that may foster a creative synthesis between history and organization studies: dual integrity, 
pluralistic understanding, representational truth, context sensitivity, and theoretical fluency. The present paper is informed by the notion of 'dual integrity', according equal weight to history and organization studies.

Allied to the above is a growing corpus of conceptually rich research that strives to reevaluate the history of management theory and practice. This entails the production of deeper, more critically reflexive and theoretically informed historical studies (Cummings et al., 2017; Durepos \& Mills, 2011; Foster, Coraiola, Suddaby, Kroezen, \& Chandler, 2017). A significant proportion of this work has appeared in the pages of $A M L E$ (Bridgman \& Cummings, 2011; 2016; Bridgman et al., 2018; Cooke \& Alcadipani, 2015; McLaren, 2019). The starting-point for many of these studies is the observation that received views about management thought can congeal over time, moulded by prevailing power relations and attendant ideologies of the Zeitgeist in which they arose (Cooke, 1999). What this emphasizes is the need purposefully to read the texts we cite on their own terms to create opportunities for re-framing. In this way, we may use them when appropriate 'to construct counter histories and new narratives about management studies' (McLaren, 2019: 44).

Drawing inspiration from the above stream of research, we situate our study within the 'historical realist' approach outlined by Vaara and Lamberg (2016). Such an approach emphasizes the historical embeddedness of strategic processes and practices, being founded on 'a realist ontoepistemological understanding of social reality that aims to reconstruct past events and to provide explanations of historical processes and mechanisms' (Vaara \& Lamberg, 2016: 634). This works well with our study, which is rooted in the socio-historical context of the aftermath of war and the economic difficulties that ensued.

In the historical realist vein, several recent studies have sought through case-based historical research to re-present management thinking and practice in the interwar period. Hassard (2012) has deconstructed the meta-narrative surrounding the Hawthorne Studies 
conducted at Western Electric (1924-1932), generally seen as the progenitor of the human relations school of management thought. The Hawthorne Studies are perceived as marking a paradigm shift from the task-oriented scientific management of Taylor (1911) to the human relations approach of Elton Mayo, championing capitalism with a 'human face'. Hassard points to the fundamental flaw in the story. The ostensibly 'progressive' ethos of the human relations philosophy, seemingly born in sociological enlightenment, belied a 'hard-edged paternalism and tough-minded anti-unionism' (Hassard, 2012: 1431). In other words, the incentive for introducing nominally 'progressive' practices lay straightforwardly in the desire to bolster a specific type of liberal political economy against the spread of trade unionism and socialist ideas. Bruce and Nyland (2011) argue that the human relations school was a rightwing, undemocratic movement whose raison d'être was to confront the demands of unions for a meaningful role in managerial decision-making. O’Connor (1999) suggests that reputedly 'progressive' practices were motivated by the desire to preserve capitalism by curtailing unionism. According to this view, cooperation and rewards for good work were emphasized to encourage acquiescence and shore up the authority of employers (Bendix, 1956), which constituted the 'natural order of things' (Bruce \& Nyland, 2011: 401).

In similar fashion, Rowlinson (1988) challenged the much-vaunted narrative of ‘industrial paternalism' or 'enlightened entrepreneurship' identified in Britain with welfarist Quaker employers like Cadbury. He argues that this obscures the alacrity with which they embraced scientific management following the publication of Taylor's Principles in 1911. This is exemplified by the regular meetings that took place between American and British industry representatives during the interwar period, designed to provide representatives of British industry with guidance and support in negotiating the various challenges before them (Kipping, 1998). Such meetings were indicative of the Americanization of management practice and learning taking place in Western Europe and elsewhere (Engwall \& Zamagni, 
1998; Tiratsoo, 2004), designed to help deal with industrial crises, labour unrest, or improve efficiency and productivity (Kipping \& Tiratsoo, 2002). Kipping (1997) identifies a burgeoning group of so-called 'efficiency engineers' who boosted the introduction of novel methods not just in the U.S. but further afield. He observes that the popularized variant of scientific management advocated by the Bedaux Consultancy enjoyed notable success in the U.K., at a time when expert views attracted particular credence (Weatherburn, 2014).

\section{Challenging the Dominant Narrative}

Critical studies of the kind considered above have drawn attention to the need to look afresh at conventional histories to question underlying assumptions and recalibrate received views, where appropriate. In this way, they help to 'stimulate more debate about management's backstory and its role in producing a certain kind of knowledge (and how this may repress thinking otherwise)' (Cummings et al., 2017: 320). In the spirit of such studies, this paper questions the conventional narrative pertaining to the resistance exhibited by British business to new management ideas during the interwar years. It is appropriate at this point to articulate this narrative more explicitly.

The Chandler-inspired approach tends to present the U.S. as the leading exponent of managerial, corporate capitalism, with Britain languishing in a more restricted phase of personal capitalism of family-owned and controlled firms (Chandler 1990). While Chandler's views have long since been critiqued (Hannah, 1983), nevertheless the literature on interwar British industrial management remains severely critical. The ideal against which British firms are measured (and found wanting) is the U.S. model. Wilson and Thomson (2006: 32) state that, unlike American, German or Japanese business, invigorated by 'rationalization, which in turn led to strategy and an orientation to further innovation', British manufacturing failed to think systematically and remained dominated by rule-of-thumb methods (McIvor, 1987). At a time when the university-based business school took root and flourished in the U.S. 
(Khurana, 2007), British universities were suspected of actively diverting graduates from a career in industry (Sanderson, 1972).

The grip of tradition on British business culture is emphasized in this literature. Wilson (1995: 156) argues that British managers eschewed new ideas and approaches to focus instead on 'bread-and-butter' issues. He suggests that by 1940, attitudes to management and its practice showed little sign of change. Child (1969) agrees that British industry during the interwar years remained stubbornly indifferent to innovative concepts. He notes that one commentator of the day 'could in 1930 chastise the great bulk of British employers, particularly those in the coal, iron and steel, cotton, woollen, pottery, and gas industries, for their conservative individualism, opposition to business education, ignorance of research findings, nepotism, and secretiveness' (Child, 1969: 103). Wilson (1995: 156) questions the degree to which the British interwar management movement made any difference to business practices. Wilson and Thomson (2006) suggest that most managers were unaware of new schools of management thought as they went about their daily business, exhibiting little interest in organizing or forward planning. Indeed, Wilson and Thomson (2006: 181) criticize the management movement as small-scale, lacking institutional support, and beyond the ambit of most managers, who 'had they been aware of what it was arguing, would have been dismissive'. The MRGs, meanwhile, are depicted as unconcerned with innovative research or of attaining a broad, national audience. Despite this pessimistic assessment, Wilson and Thomson (2006: 182) acknowledge that they clearly had some value and that "their records would repay quarrying as an indicator of the issues of the time'.

We have sought to recover, read and analyse the Rowntree material to discern more precisely the main currents in management thought and practice, enabling us to establish the scale of interest in progressive management theory and practice. The recovery of such documents was not straightforward. In addition to negotiating access, arranging, ordering, 
and weeding material, and dealing with issues of copyright and digitization, it entailed numerous repeat visits to different archives as we sought to locate and track down missing documents.

The history of British management in the interwar period, we suggest, merits reconsideration. Recent research has begun to explore how professional and scientific networks rather than familial relationships helped to create research and development capabilities in large British companies during the interwar years (Divall, 2006). We contribute to this revisionist research agenda by offering a provisional reinterpretation of British management theory and practice during the interwar period, repositioning British business and management learning initiatives relative to extant historiography. In exploring archives, and making the material thereby recovered available through our online database, we hope to encourage other researchers to investigate the 'unexplored territory on the map of theoretical reflections' that constitutes the British interwar management movement (Schwarzkopf, 2012: 1). Our intention is to analyse the core themes of this prolonged exercise in practice-based learning and explore its impact within the context of knowledge transfer within British firms of the day.

\section{RESEARCH PROCESS}

Historical methods raise challenges for organizational researchers, given the need explicitly to spell out how interpretations follow inductively from the analysis of sources. Cummings et al. (2017: xiii) confirm that 're-digging' through archives is exacting. In our case the necessary archival work proved particularly intensive. Archives are not passive, impartial places but 'implicated in power' (Schwarzkopf, 2012: 7). There are important issues around access, copyrights, and digitization requiring consideration and negotiation. Nor can we be certain that archives themselves are complete (Cooke \& Alcadipani (2015). In our case, there was no single archive to consult. The London School of Economics' (LSE) collection of 
MRG material donated by Harry Ward nevertheless contains a vast amount of material relating to their activities. Ward served as Secretary of MRG 1, and from 1935 was chief executive of the MRGs' national organization (Wilson \& Thomson, 2006).

\section{The Rowntree Lectures}

The Rowntree lectures took place initially in Scarborough, York, Blackpool and Oxford, before settling in 1922 at Balliol College, Oxford. Commencing in April 1919, they married public policy discussions with practical demonstrations of managerial initiatives, and were so successful that they resumed four times that year, three times in 1920, 1921 and 1922, becoming a twice-yearly event thereafter (with gaps only in 1931-1932 and 1939). The lecture series comprises approximately 280 papers delivered by around 200 speakers, with about 450 firms sending participants. All lectures after April 1920 contain lists of firms attending (never fewer than 33 firms and over 70 at times of acute industrial difficulty). We estimate that on average firms sent six participants. Lecturers came from a variety of networks, such as the Ministry of Munitions, Rowntree employees, Seebohm Rowntree's U.S. contacts, including Henry Dennison, Elton Mayo and Mary Follett, and members of his political circle. There were contributions from industrialists, social psychologists, management theorists, politicians, economists, historians, foremen, forewomen, supervisors, public servants, artists and musicians. Many lectures addressed topics with which Rowntree believed managers should be familiar. They aimed to educate foremen and forewomen, then managers in general, about new ideas and methods of organization. In part, they were a philosophical exercise with Christian overtones, expressive of a faith in humanity and imbued with a 'public service' vision of industry and industrial leadership. Directors' dinners, initially by invite only, took place mainly at the Waldorf hotel, London, but as social events have left relatively few traces in terms of recorded discussions.

\section{Management Research Groups}


The MRGs were modelled on Henry Dennison's Manufacturers' Research Association initiative begun in Boston, Massachusetts, in 1922, at which senior managers from noncompeting enterprises discussed issues under a guarantee of confidentiality. Dennison described them as 'a mutual education system' (Briggs, 1961: 272). The MRGs began in 1926-27, when Rowntree, Eric Geddes of Dunlop Rubber, and C. F. Merriam of British Xylonite, supported by Lyndall Urwick - an ‘early European organizations engineer' (March, 2007: 11) - brought Dennison's initiative to the U.K. This gave rise to the large-corporation London-based MRG 1 (1927-38). Dennison's Rowntree lecture in 1926 led to others asking to join the experiment, prompting the creation of a second MRG for firms employing between 500 and 2000 employees (MRG 2, 1927-38), and a third for firms of up to 500 employees (MRG 3, 1927-38). In 1927, a fourth group (MRG 4, 1927-38) of small firms was established. The make-up of groups was complex and changeable, with some disbanded in one location and reformed elsewhere. Initially they were organized by region - the North, Midlands and London - but with time they divided based on size and location to avoid the representatives of smaller firms having to journey long distances. A small number of universities also became members of MRGs. By the late 1930s, the MRGs comprised 119 firms in eight sub-sections, each located in a different city. On average, 99 firms attended each year over the study period. Notably, the MRGs flourished in the depths of the Great Depression (1929-1933), with membership peaking in 1931 at 121 firms (see Table 1).

\section{[Insert Table 1 here]}

Given that these activities were taking place in real time, understandably there were resignations from the MRGs, due to limited executive time, bankruptcies, mergers, or serendipity. Resignations were accompanied by regular co-options of new members. The average duration of membership was four years and nine months, with 14 firms staying the course throughout the entire period (see Table 2). 
[Insert Table 2 here]

The London-based MRG 1 attracted large firms drawn from a broad spectrum of manufacturing, but the provincial groups comprised smaller firms from a narrower industrial base. Groups tended to meet regularly, often undertaking case studies of member firms. We know that MRG members often kept proceedings confidential. The directors' dinners, however, presented an open debating forum. There are significant analytical difficulties arising from variabilities in the quality and quantity of surviving material, and major archival gaps relating to smaller firms and managers below executive director level.

\section{Data Sources}

Exhaustive archival research in London, York, Warwick and elsewhere has enabled the research team to assemble digitized copies of surviving, sometimes fragile, documents from the Rowntree lectures and MRG meetings that form a major part of our interactive on-line research database. We visited a large number of archives over a period of three years. These included the Alfred Gillett Trust; Bodleian Library, University of Oxford; Borthwick Institute for Archives, University of York; Bristol Archives; British Library; London Metropolitan Archives; LSE Special Collections; Modern Record Office, University of Warwick; National Archives; Nottinghamshire Archives; Suffolk Records Office; Unilever Art, Archives and Record Management; University of Reading Special Collections; and Walgreens Boots Alliance Heritage. In doing so, we gathered material relating to the movement's impact on individual firms, including Boots, British Xylonite, Clarks, Dunlop, Lyons, Rowntree's, and Imperial Tobacco. We photographed documents to avoid damaging the originals and used optical character recognition (OCR) software to generate searchable text files. The database includes copies of all Rowntree lectures located. It features the annual reports and bulletins of the MRGs (1927-1937) detailing examples of activities such as site visits and sub-committee 
deliberations, including those of buyers, engineers and senior managers, and reports on discussions following directors' dinners.

Serendipity is one of the pleasures of conducting archival research. The research team uncovered substantial new material in the archives of the LSE in the form of nine audio tapes containing 18 hours of recorded interviews with MRG organizers, notably Harry Ward. Shirley Keeble recorded these at the LSE in 1979 under the direction of Leslie Hannah. There are no surviving transcripts of the tapes, and to our knowledge, the interviews were never used as a source of project data. After receiving permission, we brought the tapes to the Digital Humanities Lab at the University of Exeter to digitize and transcribe them.

In tandem with archival research, the research team created biographical summaries primarily from publicly available sources of key Rowntree lecture and MRG participants to create a 'Who's Who' in the British interwar management movement. Its purpose is to enable a mapping of the networks of association that formed the communities of practice that Rowntree and his associates were engaged in creating (Maclean, Harvey, \& Press, 2006). Our database uses the archival software Omeka, an interactive searchable system.

Our objective is to provide a public-facing website that is free to use, providing texts of the lectures, biographies of speakers, MRG bulletins and annual reports, directors' dinner reports, and details of firms attending meetings. We hope to encourage other researchers 'to actually read the texts that we cite and use them to construct counter histories and new narratives' (McLaren, 2019: 44). We agree with Smith and Umemura (2018) that, ideally, data gathered at public expense should be made available to fellow scholars, who may lack the funds to travel to distant archives. However, such suggestions rely on the conditions of access of archives and those pertaining to the donation of materials. Making our data freely available has not been without its challenges. These include the labour-intensive demands of providing word versions of the written documents we photographed and consulted, 
necessitating extensive proofreading. The costs and practical difficulties associated with creating an online database were sizeable. In this regard, external funding proved invaluable. However, creating a data repository also generates opportunities. It enables us to fulfil the requirements of research openness and transparency advocated in this journal by Schwab and Starbuck (2017). It adds to the credibility of our research while promoting trust among interested scholars; enhancing the legitimacy of the increasingly influential community interested in the history of management learning and education. Moreover, it strengthens the validity of our claims by allowing other researchers to consult, verify, and indeed re-use our data (Aguinis, Ramani, \& Alabduljader, 2018).

\section{Data Analysis}

Building theory from historical organizational research requires that methods of data analysis be explicitly articulated. Our initial reading of the body of texts we assembled drew on recent literature, as outlined in our literature review. However, we sought to consider the material with fresh eyes, stripped of its ideological distortions, to remain amenable to discovery. In reading the material, we were alert to evidence of shared assumptions that might suggest an emerging climate of ideas in which management reformers operated, indicative of an interwar business ideology and emerging management consciousness (Maclean, Harvey, Suddaby, \& O’Gorman, 2018b; Urwick, 1956). We discerned initial themes by re-reading the texts, but when coding commenced we progressively honed our ideas (Berg, 2009; Miles and Huberman, 1994). Two members of the research team coded the texts independently, with disparities resolved through debate. After several rounds, we succeeded in categorizing each first-order text segment as mapping to one of six second-order themes that generated three aggregate themes, as outlined in Table 3 (Gioia, Corley, \& Hamilton, 2013). We next provide further contextual details to locate our study in time and space before presenting our findings.

\section{THE ROWNTREE LECTURES AND MRGS BETWEEN THE WARS}




\section{Historical Context}

Hassard (2012: 1433) contends that contextual issues merit greater attention than they often receive, to provide a 'richer and wider canvas' for historical analysis. The Zeitgeist of the interwar period (Cooke, 1999), as far as British managers were concerned, was dominated by a perceived need to avert crisis (Rowntree, 1922a). World War I had changed the spirit of the times irrevocably. British management thinking between the wars grew out of the notion of crisis avoidance, to which it formed in part a practical response. The problem of structural adjustment loomed large as the old staple industries of textiles, coal, iron, steel and shipbuilding wrestled to regain their pre-war pre-eminence in a changed international economic order. The scale of the problem was first exposed by the economic downturn that began in April 1920 and confirmed by persistently high levels of unemployment in blighted regional economies. Newer industries, such as chemicals, electrical engineering, and motor vehicles did emerge during the 1920s, many growing out of the needs of war (Sanderson, 1972). They grew vigorously alongside the service sector in the 1930s. Many nascent industries (but less so the services) were represented at the lectures and in some MRGs. The Zeitgeist, however, exacerbated by the General Strike of 1926 and the Great Depression (1929-1933), was one of lost confidence and being on the industrial back foot as other nations, notably the U.S., came to the fore economically (Alford, 1972; Broadberry, 2005).

Interestingly, the Rowntree lectures attracted their maximum attendances at times of difficulty: in 1926 immediately after the General Strike and in 1931 while Britain was deep in recession. Rowntree's own firm almost went bankrupt in 1931, outrun by Cadbury, before its renaissance in the mid-1930s (Fitzgerald, 1995). Part of Rowntree's motivation for these initiatives was therefore also to help himself. Indeed, the MRGs reported amid the depression that given the 'duress of the times, the activities and potentialities of the Group tend to be appreciated and utilised with increasing seriousness' (MRG, 1930: 26-27). This point was 
reiterated two years later: 'perhaps because of the difficulties of the times, the use made by members of the facilities offered by the Group organisation has shown a considerable intensification by comparison with the previous year' (MRG, 1932: 9). The activities of the MRGs included disseminating new ideas by means of printed reports and exchanges of information through factory and office tours and allied discussions. They established links with professional agencies targeting specific aspects of management problems. They also furnished an advice service to members. In this way, the groups sought to provide a set of stable contacts to enable member firms to problem-solve with other industry practitioners. Groups formed sub-committees (e.g. purchasing managers, personnel, and plant engineering groups) to address specific issues. From the above statements, we infer that members found the activities provided to be especially valuable in difficult times.

In an unpublished memorandum from 1917, Seebohm Rowntree outlined the rudiments of his idea for post-war management conferences to provide management education for British employers, refined by his visit to the U.S. in 1921. He explained his thinking as follows:

'I am sure that in the future we must seek to educate all members of the executive in the best methods of conducting their managerial duties. Up to the present, we have been largely content to allow them, from the highest to the lowest, to educate themselves. But if we are to create in the works the spirit which we desire, we must not only consider changes of method, but ensure the application of every method in the best possible manner'. (Briggs, 1961: 161)

Herein lay 'the germ of two of Rowntree's most creative post-war activities', the Rowntree lectures and the MRGs, to help realize his vision of providing an education for managers (Briggs, 1961: 161). This implied a shift from learning by doing to educating: systematizing management knowledge, organizing knowledge, and moving away from rules of thumb (Rowntree, 1922b). The purpose of the lectures, articulated at a conference in Woodbrooke, Birmingham, in April 1918, was summarized as follows: 
'the hope was then expressed that it might be possible to arrange for Conferences with Managers and Foremen of Industrial Firms so that they should have the opportunity of becoming acquainted with both the employers' and the workers' point of view, and also of acquiring a broad, sane outlook on human and industrial relationships' (Arnold S. Rowntree, 1919: 1).

The fact that trade union membership was rising, growing from an estimated 1.5 million in 1892 to more than 5 million members in 1920, further sharpened resolve (Wrong, 1920).

\section{Three Dominant Themes}

Systematic analysis of the Rowntree lectures and MRG documents using the method pioneered by Gioia et al. (2013) led to the identification of three dominant themes, which we explore in the sections that follow. First, is the idea of business as service, a notion close to Rowntree's heart, which quickly permeated the discourse of the movement. This represented a new perspective on industry that recognized the need to address worker discontent by promoting industrial democracy. Second, is widespread acceptance of the need to codify management knowledge, embracing the idea that managers should purposefully engage in learning about management theory and practice. Third, is promotion of the power of communities of practice as a mechanism for peer-to-peer learning, whereby managers operating in different contexts might learn from one another by exploring similar opportunities and challenges. Table 3 provides illustrative quotations for each theme, which we amplify below. We then briefly consider, illustratively, aspects of the documentary record that point to the need to revise contemporary understandings of the issues concerned. These concern what we might learn from interwar communities of practice, how best to incentivize senior managers, and the origins of personnel management as a distinct business function.

[Insert Table 3 about here]

\section{Business as Service}

Key to Rowntree's idea of management education was the concept of 'business as service', the belief that industry was a service provided in the collective national interest. The war had 
left a deep imprint on the social fabric, in which the notion of national service was very much ingrained. As Arnold Rowntree stated at the inaugural 1919 conference in Scarborough:

'In these days, when it is so difficult to forecast the future, the writer feels sure that those responsible for the management and administration of industrial concerns would do well to meet together for open and friendly conference, to consider the best way of moulding our industrial life that all those engaged in it may feel that they are taking their part in an important piece of national service'. (A. S. Rowntree, 1919: 1)

In highlighting the importance of forward planning, the above extract reveals a different side to British management, gainsaying the emphasis on the traditional rule-of-thumb approach or 'unsystematized management' (Wilson \& Thomson, 2006: 31). Taking a long-term view in the national interest was one of the things the Rowntree lecturers brought to the table.

A related lecture delivered at the same conference by A.M.P. Fleming emphasized that 'the industrial edifice... must be cemented, not merely with the economic instinct, but with the spirit of service - since industry is really a vast national service, whose function is to make nature's treasures and resources of benefit to the whole community'. Rowntree employee W.L. Hichens affirmed this, writing in the company magazine that:

'Unless industry is really recognized as primarily a national service, in which each individual is fulfilling his function to the best of his ability for the sake of the community, in which private gain is subordinate to public good, in which, in a word, we carry out our duty towards our neighbour - unless we build on this foundation, there is no hope of creating the House Beautiful'. (Hichens, 1921: 7)

The sentiments expressed here, and in similar lectures and writings, were first that business had a 'social purpose' (Wrong, 1920: 2) and was hence a national service in which individuals at all levels should play their part. Second, business should serve the interests of the whole community. Lastly, private gain was subordinate to public good. This ethos seemed to commentators to be fundamental to successful reconstruction following the war.

Allied to the notion of business as service was an explicit acknowledgement of the need for industrial democracy to address widespread worker discontent. As speaker Jimmy Mallon (1924: 10) asserted, only when the dockers chose to rebel against 'reprehensible and 
anti-social conditions which might have continued for ever... was anything done'. Mallon (1924: 11) recognized that, in the workers' eyes, even the best employers appeared 'involved in a ruthless scheme'. Workers in shipbuilding, engineering and mining, he observed, regularly earned less than the amount specified by Rowntree (1918) as a living minimum (as indeed did some of Rowntree's own workers). Rowntree (1921: ix), who served as Labour Director in the family firm, conceded such points, observing: 'No system of labour management will succeed which does not take this demand of the workers fully into account'. As a Quaker, he believed that people were born equal. His father, Joseph, had instilled in him that employees were 'fellow-workers in a great industry', such that Rowntree refused political honours and a seat in the House of Lords because it would divide him from his fellow men (Briggs, 1961: 99). This helps to explain why the lectures and MRGs were conceived in novel fashion to break through differentiated levels in the industrial hierarchy, modelled on the practice introduced at the Ministry of Munitions during the war, whose lessons Rowntree sought to incorporate.

At the opening conference in Scarborough, Rowntree entreated workers to cooperate with management in their joint interests; explaining that he required their help to succeed: 'I want to do the square thing. I believe that I can make my business successful, not only to my own advantage, but to that of the workers, if we co-operate. But I need your help, and I need your perfectly frank criticisms'. (B.S. Rowntree, 1919: 16)

Rowntree (1919: 18) therefore appealed to workers to 'play the game', adding: 'Be true umpires! See that the game is played fairly and cleanly on both sides, yours as well as mine!' However, his plea for cooperation and insistence that the workers' viewpoint be taken fully into account may have concealed a deep-rooted unease about fostering conditions in which socialism might thrive. This might suggest that the underlying raison d'etre of the notion of 'business as service' was in fact a desire to shore up a particular form of capitalism, despite employer protestations to the contrary. 


\section{Codifying Management Knowledge}

One of the most interesting aspects to emerge from the Rowntree material is that it paints a picture of the beginnings of codified management knowledge in the U.K. This reveals conference representatives and MRG members actively engaged in working out reflexively how best to manage before the emergence of Business Schools (Keeble, 1992), at least in the U.K. if not the U.S. The U.S., the sole country to experience the extensive growth of university-based Business Schools in the early twentieth century, boasted 'more than 170 departments of business administration at major universities' (Urwick, 1956: 14). However, several universities in the U.K. did offer management subjects (Tiratsoo, 2004), including the University of Birmingham, established in 1900 with the goal of improving British competitiveness (Kadish, 1991; Sanderson, 1988). The founding professor of its Faculty of Commerce, William Ashley, who had previously worked at the universities of Harvard and Toronto, introduced a B.Comm degree in 1902 designed to produce British captains of industry. The Faculty's advisory body drawn from local executives included the Quaker chocolate maker George Cadbury (Sanderson, 1972).

Our data testifies to the academic support received by the movement from a variety of higher education institutions, including the universities of Birmingham, Cambridge, Leeds, Liverpool and Manchester, alongside Regent Street Polytechnic and the LSE. Perusal of the biographies in our database testifies to the industry-academe collaboration that characterized the movement. The academics who contributed to the Rowntree conferences and MRG activities came from a wide range of disciplines. It is appropriate at this juncture to highlight some exemplars. George Allen studied under William Ashley at the Faculty of Commerce in Birmingham. He gained an M.Comm in 1921 and authored books on industrial development in Birmingham and Japan. Aged just 29, he became the first professor of economics and commerce at Hull University College. Allen argued strongly in favour of increased 
cooperation between firms and more professional management. Charles Fay was a Cambridge-educated economic historian who taught at Cambridge and the University of Toronto. Fay was keenly interested in the co-operative movement and the concept of copartnership between workers and employers. In keeping with the notion of 'business as service', his lecture to the Rowntree conference in 1920 emphasized that every career should be seen as 'social service' (Fay, 1920: 20). Murray Wrong, a historian who became VicePresident of Magdalene College, Oxford, in 1924, provides our third illustration. Wrong's contribution merits attention not just as a Rowntree lecturer, who argued that management had a role to play in mediating between capital and labour, but as the reason why the conferences moved to Balliol College, following his marriage to Rosalind Smith, daughter of the then Master of Balliol College. Notably, all three did historical research and all three had ties to North America. The decision of British managers to collaborate with academics such as Allen, Fay and Wrong provides compelling evidence that they were indeed interested in innovation and not as closed-minded and anti-intellectual as the stereotype portrays. The active participation of academics identifies the conferences and MRGs as venues where academics exchanged knowledge with practitioners. This demonstrates that interwar British managers understood the importance of seeking out and applying the knowledge possessed by scholars at Britain's fledgling Departments of Commerce, in addition to other faculties.

On a more practical level, the MRGs undertook the necessary research to expand their understanding of management practice through questionnaires regularly issued to members on a variety of topics. The MRG movement's central office helped transfer the knowledge acquired to members by 'act[ing] as a clearing-house for management information' (MRG, 1929: 6), circulating pamphlets and reports and lending out books on management from its library. However, as speaker Professor Graham Wallas (1924: 8) argued in 1924: 'we must not only acquire knowledge... we must arrange our knowledge' (our emphasis). Arranging 
or codifying knowledge was an idea that, for Rowntree, held merit. As the minutes of a subcommittee on higher administration and control recorded, 'Mr Rowntree... thought it would be a good idea if someone could draw up a statement summarising the facts necessary for running a business' (MRG 1 Minutes, 1929b). Members concurred that it was 'an important part of the work of the Movement that authoritative statements on management subjects be issued' (MRG, 1930: 3).

Summarizing business knowledge required a priori that key terms be defined, in particular administration, management and organization, for which the large London-based MRG 1 proposed definitions. Administration, or strategy in current parlance, was defined as: 'the function in industry concerned in the determination of the corporate policy, the co-ordination of finance, production, and distribution, the settlement of the compass of the organization, and the ultimate control of the executive'. (MRG 1 Minutes, $1929 b)$

Management, by contrast, related to 'the execution of policy, within the limits set up by administration'. Organization pertained to 'the formation of an effective machine'. The three connected as follows: 'Administration defines the goal; management strives towards it. Organization is the machine of management, in its achievement of the ends determined by administration' (MRG 1 Minutes, 1929b).

One of the important issues with respect to the Rowntree lectures and MRG movement is the extent to which new ideas filtered through to firms attending. With regard to Rowntree's, which benefits from extensive records at the Borthwick Institute for Archives, there is evidence in company papers of painstaking attempts to pass on acquired learning more widely within the firm. This is exemplified by the following explanation of 'functionalization' in the company's magazine:

'Functionalization... is a principle underlying management just as "democratization" is a principle underlying political government... Functional management relies for its success in operation of specialization by functions of manufacturing, centred in a staff of men rather than in one head who is supposed to be qualified to direct all of these functions himself'. (Anon., 1921: 75) 
Our data reveals British business leaders vigorously debating the 'requirements of an ideal organisation, as suggested by Oliver Sheldon' (MRG 1 Minutes, 1930). Subjects discussed at meetings were wide-ranging, pertaining to both the macro- and micro-level, external and internal to the firm. Topics included: how to avoid industrial depression; how responsibilities should be divided among personnel; the art of control; motion studies; heating; advertising; the recruitment and training of salesmen; holiday payments; stock control; costing; waste reduction; and the influence of Garden Cities. Directors' dinners likewise covered considerable ground, debating such diverse issues as: the principles of modern production planning; how to measure the effectiveness of advertising; absenteeism caused by illness; and how to get the best out of second and third line executives.

\section{The Emergence of Communities of Practice}

Representatives of participating firms repeatedly emphasize in our data the value of gathering together for lectures, meetings and dinners. Referring to the preliminary lecture conference held in Birmingham in 1918, Arnold Rowntree (1919: 1) expressed the view that 'it is quite impossible to convey through printed matter the "atmosphere" that pervaded the Conference or the sense of good comradeship and friendship which abounded'. Our data reveals that members experienced meeting up in this way as participation in self-help communities of practice. New members joined existing groups based on common interests to preserve group integrity, 'care... being taken to select additional members with closely allied interests' (MRG, 1929: 24). Referencing the 'close contact and mutual help' facilitated by groups, the MRGs' (1929: 1) third annual report cites a passage from the first MRG publication (General Series no. 1):

'Only when every executive officer in each firm thinks immediately he is confronted with a new problem - "I can get help from $\mathrm{A}$ and $\mathrm{B}$ and $\mathrm{C}$ - executives in other Companies - on this" can the Group idea be said to be established'. 
The report encourages such contact at every level of the organization, so that the ‘collaborative learning process of "thinking together"” (Pyrko, Dörfler, \& Eden, 2017: 389) might occur up and down company hierarchies:

'But Directors of Member Companies and those officers who have attended meetings can do much to help it forward by encouraging their staffs of all grades to get into contact with their "opposite numbers" in the other Companies in the Group'. (MRG, 1929: 1)

The annual report for the following year affirmed that the process of 'groping for and trial of minor alterations', as members grappled with 'identical, similar or analogous problems', was exceedingly valuable. In this way, 'any individual who has attended say half a dozen sessions and finds that he has wasted his time and gained nothing has qualified... for admission to an occupation centre for the ineducable' (MRG, 1930: 27).

The material is replete with evidence indicative of the conscious formation of active communities of practice, infused with the 'shared sense of purpose' identified by Thompson (2005: 151). On the merits of convening as a community of practice engaged in peer-to-peer learning (Wenger, 1998), members of MRG 1 were of one mind:

'Apart from any value that the investigation has been to members, it has proved an invaluable means of becoming acquainted with a large number of executives and many inquiries have been answered and information exchanged during the personal contacts made'. (MRG 1 Minutes, 1930)

Mr Crabtree of J.A. Crabtree \& Co, Walsall, summed up what engaging in a community of practice had meant for him personally. It had, he claimed, galvanized his ambition and resolve to do better: 'I do not know how the other men feel, but the effect on me has been almost competitive, in the old school sense "that if [X] can do it, why can't I?"' (MRG, 1927: 13). While 'the technique of Group work [was] still fluid' (MRG, 1931: 1) as members felt their way in the process, the benefits of working together were such that members believed they should be shared more widely across British industry:

'if the idea of co-operation in the discussion and solution of management problems by manufacturers, and the exchange of information on management matters, is valuable, 
we want to see the advantages shared by an ever widening circle of British industrialists'. (MRG, 1931: 2-3)

Knowledge transfer was central to the establishment of active communities of practice, 'exchanging the merchandise of experience' (MRG, 1932: 8). To promote knowledge transfer, expert speakers, including Elton Mayo, were regularly co-opted to address members, especially those of MRG 1, placing 'their expert knowledge and special experience at the disposal of the various sections of the Group' (MRG, 1931: 12).

The knowledge shared by these means was first and foremost practical. This is summarized as follows: "“Theory", you say. "What about practice, that is our test"” (MRG 1 Minutes, 1930). Indicative of this practical orientation, site visits quickly became a regular event, members having decided early on that 'visits to each other's offices could be arranged when mutual benefit seems likely to arise' (MRG 1 Minutes, 1929a). Seebohm Rowntree initiated these in 1927, inviting members to Rowntree \& Co Ltd. in York (MRG, 1927: 4). Other firms followed suit. British Xylonite introduced site visits within its factory for its own employees, to enhance knowledge capture within its premises, announcing 'we have started the Group idea in our own factory by arranging visits of all departmental managers to the various departments in turn, when detailed explanations of the processes are given' (MRG, 1927: 15). The utility of these visits was such that they were expanded to embrace office visits, beginning in 1935 with one to toothpaste manufacturer Macleans Ltd (MRG, 1935a: 14).

It would be erroneous, however, to present the unfolding of MRG activities as consistently straightforward. The annual report for 1929 laments the fact that the provisional committee established to devise a scheme for collaboration amongst members had 'not been wholly a success' (MRG, 1929: 25). Similarly, the annual report for 1935 bemoans the sparse attendances that had hampered the activities of MRG 3 in that year, stating: 'too small a 
meeting creates a risk that the amount of information and knowledge available for exchange may be too small' (MRG, 1935a: 13).

\section{Illuminating 'contemporary' issues}

In addition to the three dominant themes to emerge from our data, we found that perusing management history in the manner encouraged by Cummings et al. (2017) sparked new understanding on specific issues. As Cummings and Bridgman (2011: 89) argue, history 'is written for the present and we can expect it to be rewritten again for future generations... in such a way that connects to the issues of the day'. In our own case, we were struck by the insights it provoked regarding supposedly 'contemporary' issues, revealing that such issues were very much alive in the interwar period.

This applies to communities of practice. While Lave and Wenger did not coin the term until 1991, our study uncovers thriving communities of practice actively at work 60-70 years previously. Communities of practice can lack the opportunity for sustained engagement, but our longitudinal research illuminates the manner of their interaction over time (Thompson, 2005). We show this to be a collaborative relational process marked by a growing sense of identification with a shared repertoire (Wenger, 1998), built around real-life issues (Pyrko et al., 2018). While communities of practice often fail because they are hierarchically 'set up', our study suggests that today's communities of practice might be more effective if they were organically derived - resulting from a genuine common purpose - as in the interwar years when managers faced a pressing need to avert crisis. This required the pooling of expertise at a time when forces majeures demanded their cooperation.

A further illustration is the topic of executive remuneration, commonly understood to have come to the fore in the U.K. with the publication of the Greenbury Report in 1995, following exorbitant pay increases awarded to executives of privatized utilities (Harvey, Maclean, \& Price, 2019; Maclean, 1999). Our data reveal that MRG groups were grappling 
with the issue more than half a century earlier, commencing in 1931 when 'a comparison of higher executives' salaries by a small hand-picked meeting... broke new ground' (MRG, 1931: 15). A sub-committee was established in 1935 to consider the 'Remuneration of Senior Executives'. The entire membership of the movement was requested to contribute (MRG, 1935b: 2). 'Incentives for Executives' were debated at a directors' dinner in 1935 (MRG, 1935b: 4). In response to a query concerning the practice of executive bonuses in the U.S., a certain Professor Balderston sent a lengthy reply. This contained the following insight:

'The depression experience has strengthened my doubt as to the wisdom of coupling stock ownership with managerial profit-sharing, except for officers of the highest rank. I would add that even the highest officers should not be permitted to become so involved financially with a proprietary interest in their own concern that they will be spoiled as executives if the prices of the company's stock decline because of forces that they cannot control.' (MRG, 1936a: 2)

The practice of aligning executive pay with company performance and shareholder interests by means of stock options attracted public attention in the early 2000s, as part of a new creed of maximizing shareholder value that had risen to prominence on both sides of the Atlantic (Lazonick \& O'Sullivan, 2000). Yet here we can see MRG members wrestling with this thorny issue 70 years previously. Extracts such as the above suggest that the interwar advocates of 'business as service' were against the use of stock options. One aspect in which executive remuneration diverged markedly from contemporary practice, however, was in the absence of pay rises between the wars. As Harry Ward explained from the vantage point of the late 1970s:

'It was normal for the head of an institution, the Director or Secretary, to be paid a particular salary on appointment, and there was no question for 10, 20 or even more years of even altering that salary. Now, of course, it is suggested that there should be salary increases every year, but it wasn't remotely the position in the interwar years'. (Ward, 1979, tape 1: 5).

We know from recent historical research that the doctrine of shareholder primacy has been challenged regularly throughout British legal history from the seventeenth century to the 2006 Companies Act (Moore, 2018). Here, in the aftermath of World War I, which 
dramatically altered the nature of British society, we see managers conceptualizing their role as serving society more broadly. The ethos of corporate social responsibility which 'business as service' denotes is arguably indicative of a longer history of socially responsible business practice than is often assumed (Husted, 2014; Smith, 2017).

Similarly, received wisdom holds that the personnel function grew out of World War II, arising from the demands of the state in a wartime economy, which bureaucratized employment relations. Baron, Dobbin and Jennings (1986) trace the development of bureaucratic controls in the U.S., attributing these to the vital role played by government demands for information, which assisted the growth of personnel professionals who gathered, collated and recorded this data. Our data reveal MRG members discussing the introduction of the personnel function in the 1930s, prior to World War II. One unnamed firm records the difference to their business made by the appointment in 1934 of a personnel manager, in terms of improved employee relations, reduced labour turnover, and fewer days lost to strikes (MRG, 1936b). A later MRG (1936c: 3) bulletin reproduces an advertisement published in The Times for a personnel manager. While 'no previous personnel experience [was deemed] necessary', the firm sought a 'man with strong personality and interest in human problems of management'. Our findings support those of Thornthwaite (2012: 312), who finds that a model of personnel management developed in colonial public services in late nineteenthcentury Australia, much earlier than commonly assumed. Our data thus provide, or corroborate, insights that can challenge our understanding of what we knew, or thought we knew, about such issues.

\section{DISCUSSION AND CONCLUSION}

In this paper, we aim to reappraise the British management research movement of the interwar years. This has entailed interrogating archival data to re-imagine interwar management history, in the fashion encouraged by recent commentators (Cummings \& 
Bridgman, 2011; 2016; Cummings et al., 2017; McLaren, 2019; Scranton \& Fridensen, 2013). Our study offers a radically different vision of British management history in the 1920s and 1930s to the declinist, languishing picture often presented. We reveal, in contrast, a more nuanced picture, uncovering vibrant communities of practice actively engaged in promoting practice-based, peer-to-peer learning designed to accelerate the diffusion of effective solutions to common problems. The Rowntree lecture series mixed discussion of public policy issues with practical demonstrations of progressive management initiatives. The movement's leaders assembled a wide array of what they believed enlightened British managers should know, far exceeding the improvement of human relations in the workplace. The MRG material reveals its members to be engaged in researching a broad range of issues from which they could learn. According to Harry Ward (1979: 17), the movement 'had a great influence on the country and on industry', representing 'a fair proportion of the most progressive Companies in this Country' (MRG, 1935b: 2).

Taking a fresh historical perspective can trigger new research questions while inviting re-examination of existing questions. Earlier we enquired to what extent our research might indicate a greater openness to management learning and novel ideas, coupled with a willingness to discuss problems, than is commonly acknowledged. In answer, we suggest that interwar firms were relatively comfortable with routine management practices until participation in external networks driven by the need to avert crisis and facilitated by the Rowntree lectures and MRGs opened their eyes to new routines, structures and knowledge outside their customary ambit and experience. In altering the prevailing Zeitgeist, war had increased the value of ideas, showing how entire nations could benefit from cooperation (Wrong, 1919). This suggested that non-competing firms might follow suit by daring to share knowledge and problem solve together, albeit on a confidential basis. Our research bears 
witness to the meaningful learning processes at work in surprisingly dynamic communities of practice (Pyrko et al., 2018).

However, just as the human relations approach had its roots in scientific management (Bruce, 2006; Bruce \& Nyland, 2011; Hassard, 2012; O’Connor, 1999), with which it is often contrasted, so the 'business as service' initiative may have arisen from an intense antiunionism on the part of employers. This may have expressed a fear of creating the conditions in which unionism and socialism might flourish, to which 'business as service' was designed to serve as an antidote (Renold, 1920). The stakeholder model it evoked might stem the spread of communist ideas taking root elsewhere (Barton, Horváth, \& Kipping, 2016). In this context, Quail (2000) observes that Rowntree was something of a contradiction in terms, for although ostensibly he extolled management efficiency, he was fiercely protective of proprietorial dynastic rights. Rowntree (1920: 14) spoke passionately about 'sweep[ing] away the wretched social barriers'. Yet he was angered by suggestions that his son Julian was recruited to Rowntree's 'by backstairs methods on my own part and that no proper steps were taken to ascertain that he was the best trainee it was possible to find' (Rowntree, 1932: 1). Tellingly, Ward (1979: 6) argues that Rowntree 'had a great love for humanity in general, but not for people in particular'.

At a time of growing union activism, industrial discontent, and high unemployment, the purpose of 'business as service' may have been to deflect a potentially more threatening turn of events by encouraging employee compliance with managerial authority. This might enable the 'right to manage' to be reclaimed through the validation of a managerial elite as the rightful guardians of administrative control if it could prove itself sufficiently humanist and caring of its workers. Attempts to codify management knowledge contain an element of asserting control (Vaara \& Lamberg, 2016). Considered thus, the initiative of 'business as service' is bound up with the history of the use of power and the preservation of a form of 
capitalism in which, despite the trend towards managerialism, the enduring privileges of dynastic families continued to loom large (Cooke, 1999; O’Connor, 1999).

The British interwar management movement was born in crisis avoidance, weathering the General Strike, the Great Depression, and mass unemployment. The outbreak of World War II, however, proved a different matter entirely, bringing the movement to a standstill and our period of study to a close. Records at the Imperial Tobacco Co. refer, ominously, to the setting up of an Air Raid Precaution Committee in 1935. The MRG (1937b: 13) annual report for 1937 mentions the 'organisation of fire and air raid precautions'. Many of the groups halted in 1937-38. While efforts were made to resume the movement after World War II, in the words of Harry Ward (1979, tape 1: 4), it never regained its former glory: 'Management research has never recovered to the level it was in those interwar years'.

Like all research, this paper has limitations. For reasons of space, we have not explored the degree to which the representatives of firms attending lectures and MRG meetings incorporated new management ideas in their own organizations. Further research could consider investigating the extent to which management innovations were absorbed within participating companies (Cohen \& Levinthal, 1990). Thus far, we have examined the impact of the movement through archival research at Boots, British Xylonite, Clarks, Dunlop, Lever Brothers (Unilever), Lyons, Rowntree's, and Imperial Tobacco Co., but further indepth case studies are required to assess the movement's full impact. We have concentrated in this study on manufacturing companies, service firms being poorly represented in the movement. Further research might investigate why this is so. Future research might also consider the rhetorical devices by which business leaders were persuaded to embrace new management techniques, producing a more robust understanding of the extent to which this knowledge was internally consistent and/or contested by the audience (Maclean et al., 2018a; Suddaby, Foster, \& Quinn-Trank, 2010). 
We contribute to the growing and increasingly influential literature that aims to look afresh at management history (Bridgman et al., 2018; Cummings \& Bridgman, 2011; 2016; Cummings et al., 2017; McLaren, 2019) by reappraising the British interwar management movement. We offer a new, nuanced perspective on the evolution of British management learning in the interwar years that contrasts markedly with the received, critical view outlined above. The interwar years have been regarded as something of a 'dark age' of British management. In lieu of a period of reactionary thinking with little going on, we find strong evidence of profound efforts to improve British management practices, learning and education. We uncover dynamic knowledge networks reflexively engaged in advancing and codifying practice-based learning through peer-to-peer communication to promote the spread of effective solutions to shared problems. This casts new light on the development of management education and communities of practice in the U.K. The common mind-set it denotes is indicative of an interwar business ideology (Bendix, 1956). This was founded on a principle of cooperation and an ethos of 'business as service', heightened by experience of war, and characterized by a belief in practical learning through shared problem solving. This interwar business ideology held that, in the relative absence of Business Schools, noncompeting manufacturing companies might assist one another in ways from which member firms could benefit. Our study shows that the doctrine of shareholder primacy was being challenged in interwar Britain. Going back in time in this way to rethink management history can recast understanding of current issues, enabling us to pose new questions for the future (McLaren, 2019).

We also make methodological contributions in this paper. We add, first, to the relatively sparse studies on management learning and education that are grounded in archival research (Cooke \& Alcadipani, 2015), demonstrating the deeper engagement with archives recommended by Cummings and Bridgman (2016). We have done so by creating an online 
data repository through investigating multiple archives to bring the Rowntree lectures and MRGs active in interwar Britain to the attention of a new audience of scholars, interested in how managers create and seize opportunities to learn. In keeping with recent recommendations to increase research openness and transparency (Schwab \& Starbuck, 2017; Smith \& Umemura, 2018), and indeed with the service ideology which infuses our project, this repository will make our project data available to other interested scholars. In this way, we aim to create a new 'space' (http://rowntree.exeter.ac.uk/) for future researchers to explore their own ideas within the rich landscape of the British interwar management movement.

\section{REFERENCES}

Aguinis, H., Ramani, R.S., \& Alabduljader, N. 2018. What you see is what you get? Enhancing methodological transparency in management research. Academy of Management Annals, 12: 83-110.

Alford, B.W.E. 1972. Depression and recovery? British economic growth, 1918-39. London: Palgrave Macmillan.

Anon. 1922. Ideas in management. The Cocoa Works Staff Journal. 2: 8-10

Baron, J.N., Dobbin, F.R., \& Jennings, P.D. 1986. War and Peace: The evolution of modern personnel administration in U.S. industry. American Journal of Sociology, 92: 350383.

Barton, D., Horváth, D., \& Kipping, M. 2016. Re-imagining capitalism for the long term. In D. Barton, D. Horváth, \& M. Kipping (Eds.), Re-imagining capitalism: 1-14. Oxford: OUP.

Bendix, R. 1956. Work and authority in Industry: Managerial ideologies in the course of industrialization. New Brunswick: Transaction Publishers. 
Berg, B.L. 2009. Qualitative research methods for the social sciences. $7^{\text {th }}$ edn. Boston, MA: Allyn \& Bacon.

Bridgman, T., Cummings, S., \& Ballard, J. 2019. Who built Maslow's pyramid? A history of the creation of management studies' most famous symbol and its implications for management education. Academy of Management Learning \& Education, 18: 81-98.

Briggs, A. 1961. Social thought and social action: A study of the work of Seebohm Rowntree 1871-1954. London: Longmans.

Broadberry, S. 2005. The productivity race: British manufacturing in international perspective. Cambridge: CUP.

Bruce, K. 2006. Henry S. Dennison, Elton Mayo, and Human Relations historiography. Management \& Organizational History, 1: 177-199.

Bruce, K., \& Nyland, C. 2011. Elton Mayo and the deification of human relations. Organization Studies, 32: 383-405.

Bucheli, M., \& Wadhwani, R.D. (Eds.) 2014. Organizations in time: History, theory, methods. Oxford: OUP.

Chandler, A.D. 1990. Scale and scope: The dynamics of industrial capitalism. Cambridge, MA: Belknap Press.

Child, J. 1969. British management thought: A critical analysis. Abingdon: Routledge.

Clark, P., \& Rowlinson, M. 2004. The treatment of history in organisation studies: Towards an 'historic turn'? Business History, 46: 331-352.

Cohen, W.M., \& Levinthal, D.A. 1990. Absorptive capacity: A new perspective on learning and innovation. Administrative Science Quarterly, 35: 128-152.

Conference of Quaker Employers. 1918. Quakerism and Industry, 1918. London, Friends Book Centre. 
Cooke, B. 1999. Writing the left out of management theory: The historiography of the management of change. Organization, 6: 81-105.

Cooke, B., \& Alcadipani, R. 2015. Toward a global history of management education: The case of the Ford Foundation and the São Paulo School of Business Administration, Brazil. Academy of Management Learning \& Education, 14: 482-499.

Cummings, S., \& Bridgman, T. 2011. The relevant past: Why the history of management should be critical for our future. Academy of Management Learning \& Education, 10: 77-93.

Cummings, S., \& Bridgman, T. 2016. The limits and possibilities of history: How a wider, deeper, and more engaged understanding of business history can foster innovative thinking. Academy of Management Learning \& Education, 15: 250-267.

Cummings, S., Bridgeman, T., Hassard, J., \& Rowlinson, M. 2017. A new history of management. Cambridge: CUP.

Dent, E.B., \& Bozeman, P. 2014. Discovering the foundational philosophies, practices, and influences of modern management theory. Journal of Management History, 20: 145163.

Divall, C. 2006. Technological networks and industrial research in Britain: The London, Midland and Scottish Railway, 1926-47. Business History, 48: 43-68.

Durepos, G., \& Mills, A.J. 2012. Actor-network theory, ANTi-history and critical organizational historiography. Organization, 19: 703-721.

Engwall, L., \& Zamagni, V. (Eds.). 1998. Management education in historical perspective. Manchester: Manchester University Press.

Fay, C.R. 1920. Education as a factor in industry. Lecture conference held at Durham, March 19 ${ }^{\text {th }}-22^{\text {nd }}$, 1920: 20-23.

Ferguson, M. 2002. The rise of management accounting in Britain. Aldershot: Ashgate. 
Fitzgerald, R. 1995. Rowntree and the marketing revolution, 1862-1969. Cambridge: CUP.

Fleming, A.P.M. 1919. The industrial ladder: The Fisher Act in its relation to industry. Report of lectures given at the Lecture School for Works Managers, Foremen, Forewomen. $24^{\text {th }}-28^{\text {th }}$ April: $8-9$.

Foster, W. M., Coraiola, D. M., Suddaby, R., Kroezen, J., \& Chandler, D. 2017. The strategic use of historical narratives: A theoretical framework. Business History, 59: 11761200.

Gillett, A.G., \& Tennent, K.D. 2017. Dynamic sublimes, changing plans, and the legacy of a megaproject: The case of the 1966 soccer world cup. Project Management Journal, 48: 93-116.

Gioia, D.A., Corley, K.G., \& Hamilton, A.L. 2013. Seeking qualitative rigor in inductive research: Notes on the Gioia methodology. Organizational Research Methods, 16: $15-31$

Hamilton Church, A. 1923. The compleat manager. The Cocoa Works Staff Journal, 11: $150-152$.

Hannah, L. 1983. The rise of the corporate economy. London: Methuen.

Hannah, L. 2007. The "divorce" of ownership from control from 1900 onwards: Recalibrating imagined global trends. Business History, 49: 404-438.

Harvey, C., Maclean, M., \& Price, M. 2019. Executive remuneration and the limits of disclosure as an instrument of corporate governance. Critical Perspectives on Accounting. In press. doi.org/10.1016/j.cpa.2019.06.003

Hassard, J.S. 2012. Rethinking the Hawthorne Studies: The Western Electric research in its social, political and historical context. Human Relations, 65: 1431-1461.

Hichens, W.L. 1921. Industry - a national service. The Cocoa Works Staff Journal, 1: 7. 
Husted, B.W. 2014. Corporate social responsibility practice from 1800-1914: Past initiatives and current debates. Business Ethics Quarterly, 25: 125-141.

Kadish, A. 1991. The foundation of Birmingham's Faculty of Commerce as a statement on the nature of economics. The Manchester School, 59: 160-172.

Keeble, S.P. 1992. The ability to manage: A study of British management, 1890-1990. Manchester: Manchester University Press.

Khurana, R. 2007. From higher aims to hired hands. Princeton: Princeton University Press. Kieser, A. 1994. Crossroads - why organization theory needs historical analyses - and how these should be performed. Organization Science, 5: 608-620.

Kipping, M. 1997. Consultancies, institutions and the diffusion of Taylorism in Britain, Germany and France, 1920s to 1950s. Business History, 39: 66-82.

Kipping, M. 1998. 'Operation Impact': Converting European employers to the American creed. In M. Kipping \& O. Bjarnar (Eds.), The Americanisation of European business: 55-73. Abingdon: Routledge.

Kipping, M. 1999. American management consulting companies in Western Europe, 19201990. Business History Review, 73: 190-220.

Kipping, M., \& Engwell, L. 2003. Management consulting: Emergence and dynamics of a knowledge industry. Oxford: OUP.

Kipping, M., \& Tiratsoo, N. (Eds). 2002. Americanization in twentieth century Europe: Business, culture, politics. Lille: University of Lille Press.

Kipping, M., \& Üsdiken, B. 2014. History in organization and management theory: More than meets the eye. Academy of Management Annals, 8: 535-588.

Lave, J., \& Wenger, E. 1991. Situated learning: Legitimate peripheral participation. Cambridge: CUP. 
Lazonick, W., \& O’Sullivan, M. 2000. Maximizing shareholder value: A new ideology for corporate governance. Economy and Society, 29: 13-35.

Maclean, M. 1999. Corporate governance in France and the U.K.: Long-term perspectives on contemporary institutional arrangements. Business History, 41: 88-116.

Maclean, M., Harvey, C., \& Clegg, S.R. 2016. Conceptualizing historical organization studies. Academy of Management Review, 41: 609-632.

Maclean, M., Harvey, C., \& Clegg, S.R. 2017. Organization theory in Business and Management History: Current status and future prospects. Business History Review, 91: 457-481.

Maclean, M., Harvey, C., \& Press, J. 2006. Business elites and corporate governance in France and the UK. Basingstoke: Palgrave Macmillan.

Maclean, M., Harvey, C., Sillince, J.A.A., \& Golant, B.D. 2014. Living up to the past? Ideological sensemaking in organizational transition. Organization, 21: 543-567

Maclean, M., Harvey, C., Sillince, J.A.A., \& Golant, B.D. 2018a. Intertextuality, rhetorical history and the uses of the past in organizational transition. Organization Studies, 39: 1733-1755.

Maclean, M., Harvey, C., Suddaby, R., \& O’Gorman, K. 2018b. Political ideology and the discursive construction of the multinational hotel industry. Human Relations, 71: 766-795.

Mallon, J.J. 1924. Industrial peace. Eighteenth lecture conference for works directors, managers, foremen and forewomen held at Balliol College, Oxford. $4^{\text {th }}$ April: 10-13.

March, J.G. 2007. The study of organizations and organizing since 1945. Organization Studies, 28: 9-19.

McIvor, A.J. 1987. Employers, the government, and industrial fatigue in Britain, 1890-1918. British Journal of Industrial Medicine, 44: 724-732. 
McLaren, P. 2019. Stop blaming Gordon and Howell: Unpacking the complex history behind the research-based model of business education. Academy of Management Learning \& Education, 18: 43-58.

Miles, M.B., \& Huberman, A. M. 1994. Qualitative data analysis: An expanded sourcebook. $2^{\text {nd }}$ edn. Thousand Oaks, CA: Sage.

Moore, M.T. 2018. Shareholder primacy, labour and the historic ambivalence of UK company law. In H. Wells (Ed.), Research handbook on the history of corporate and company law: 142-169. Cheltenham: Edward Elgar.

MRG 1 [Management Research Group 1]. 1929a. Minutes. LSE Library.

MRG 1. 1929b. Minutes. LSE Library.

MRG 1 Minutes. 1930. LSE Library.

MRG [Management Research Groups] (1927), First Annual Report, $\mathbf{1}^{\text {st }}$ January - 31 ${ }^{\text {st }}$ December.

MRG. 1928. Second Annual Report, $1^{\text {st }}$ January - $31^{\text {st }}$ December 1928.

MRG. 1929. Third Annual Report, 1 $^{\text {st }}$ January - 31 ${ }^{\text {st }}$ December 1929.

MRG. 1930. Fourth Annual Report, $1^{\text {st }}$ January - 31 ${ }^{\text {st }}$ December 1930.

MRG. 1931. Fifth Annual Report, $1^{\text {st }}$ January - 31 ${ }^{\text {st }}$ December 1931.

MRG. 1932. Sixth Annual Report, $1^{\text {st }}$ January - 31 ${ }^{\text {st }}$ December 1932.

MRG. 1935a. Ninth Annual Report, $1^{\text {st }}$ January - 31 $^{\text {st }}$ December 1935.

MRG. 1935b. Management Research Groups Bulletin. November, 22: 1-7.

MRG. 1936a. Management Research Groups Bulletin. January, 24: 1-6.

MRG. 1936b. Management Research Groups Bulletin. July, 26: 1-4.

MRG. 1936c. Management Research Groups Bulletin. October, 27: 1-5.

MRG. 1937a. Management Research Groups Annual General Meeting: 1-5.

MRG. 1937b. Eleventh Annual Report, $1^{\text {st }}$ January -31 ${ }^{\text {st }}$ December 1937. 
O'Connor, E. 1999. The politics of management thought: A case study of the Harvard Business School and the Human Relations School. Academy of Management Review, 24: 117-131.

Pyrko, I., Dörfler, V., \& Eden, C. 2017. Thinking together: What makes communities of practice work. Human Relations, 70: 389-409.

Quail, J. 2000. The proprietorial theory of the firm and its consequences. Journal of Industrial History, 5: 1-28.

Renold, C. 1920. The benefit to the workers of scientific management. Lecture conference for works directors, managers, foremen, forewomen held at Balliol College, Oxford. $15^{\text {th }}-19^{\text {th }}$ April: $3-7$.

Rowlinson, M. 1988. The early application of scientific management by Cadbury. Business History, 30: 377-395.

Rowlinson, M., Hassard, J., \& Decker, S. 2014. Strategies for organizational history: A dialogue between historical theory and organization theory. Academy of Management Review, 39: 250-274.

Rowntree, A.S. 1919. Introduction. Report of lectures given at the Lecture School for Works Managers, Foremen, Forewomen. $24^{\text {th }}-28^{\text {th }}$ April: 1 .

Rowntree, B.S. 1918. The human needs of labour. London: Thomas Nelson and Sons Ltd. Rowntree, B.S. 1919. Untitled address. Report of lectures given at the Lecture School for Works Managers, Foremen, Forewomen. $24^{\text {th }}-28^{\text {th }}$ April: 13-19.

Rowntree, B.S. 1920. Training for industrial administration: Lecture conference at Durham. The Cocoa Works Staff Journal, September: 13-15.

Rowntree, B.S. 1921. The human factor in business: Further experiments in industrial democracy. London: Longmans, Green and Co.

Rowntree, B.S. 1922a. Industrial unrest: A way out. London: Longmans, Green and Co. 
Rowntree, B.S. 1922b. A study of American efficiency methods. Lecture conference for works directors, managers, foremen, forewomen held at Balliol College, Oxford. $6^{\text {th }}-10^{\text {th }}$ April: $34-38$.

Rowntree, B.S. 1932. Entry of directors' sons into the business: B.S.R.'s statement to the York board. 22 November.

Sanderson, M. 1972. The universities and British industry 1850-1970. London: Routledge \& Kegan Paul.

Sanderson, M. 1988. 'The English civic universities and the 'industrial spirit', 1870-1914. Historical Research, 61: 90-104.

Schwab, A., \& Starbuck, W.H. 2017. A call for openness in research: How to turn covert practices into helpful tools. Academy of Management Learning \& Education, 16: $125-141$.

Scranton, P. 1997. Endless novelty: Specialty production and American industrialisation, 1865-1925. Princeton: Princeton University Press.

Scranton, P., \& Fridensen, P. 2013. Reimagining business history. Baltimore, MD: Johns Hopkins University Press.

Schwarzkopf, S. 2012. What is an archive - and where is it? Why business historians need a constructive theory of the archive. Business Archives, 105: 1-9.

Sheldon, O. 1923. Philosophy of management. London: Pitman.

Smith, A.D., \& Umemura, M. 2018. Prospects for a transparency revolution in the field of business history. Business History, 1-23.

Smith, C., Child, J., \& Rowlinson, M. 1990. Reshaping work: The Cadbury experience. Cambridge: CUP. 
Smith, E. 2017. Socially responsible and responsive business in seventeenth-century England. In W.A. Pettigrew \& D.C. Smith (Eds.), A history of social responsible business, $c$. 1600-1950: 65-93. Cham: Palgrave Macmillan.

Stewart, D. 1921. To what extent is democratic control of industry possible? The workers' standpoint. Lecture conference for industrial administrators and workers' representatives held at York. $13^{\text {th }}$ February: $34-37$.

Suddaby, R., Foster, W.M., \& Quinn-Trank, C. 2010. Rhetorical history as a source of competitive advantage. In J. A. C. Baum \& J. Lampel (Eds.), Globalization of strategy research, 27: 147-173. London: Emerald.

Taylor, F.W. 1911. The principles of scientific management. New York: Harper \& brothers.

Thompson, M. 2005. Structural and epistemic parameters in communities of practice. Organization Science, 16: 151-164.

Thornthwaite, L. 2012. The origins of personnel management: Reasserting the public sector experience. Journal of Management History, 18: 312-330.

Tiratsoo, N. 2004. The ‘Americanization' of management education in Britain. Journal of Management Inquiry, 13: 118-126.

Urwick, L.F. 1956. The pattern of management. London: Sir Isaac Pitman \& Sons Ltd.

Urwick, L.F., \& Brech, E.F.L. 2002. The making of scientific management. Bristol: Thoemmes Press.

Vaara, E., \& Lamberg, J.-A. 2016. Taking historical embeddedness seriously: Three historical approaches to advance strategy process and practice research. Academy of Management Review, 41: 633-657.

Wallas, G. 1924. The mental process of responsible decision. Eighteenth lecture conference for works directors, managers, foremen and forewomen held at Balliol College, Oxford. $3^{\text {rd }}$ April: 6-10. 
Ward, H. 1979. Personal interview with Dr Shirley Keeble. Harry Ward Tapes, 1-9.

Weatherburn, M. 2014. Scientific management at work: The Bedaux system, management consulting, and worker efficiency in British industry, 1914-41. $\mathrm{PhD}$ Thesis, Imperial College, University of London.

Wenger, E. 1998. Communities of practice: Learning, meaning and identity. Cambridge: CUP.

Wilson, J.F. 1995. British business history, 1720-1994. Manchester: Manchester University Press.

Wilson, J.F., \& Thomson, A. 2006. The making of modern management: British management in historical perspective. Oxford: OUP.

Wrong, E.M. 1919. A brief review of conditions in modern industry. Report of addresses given at the lecture school for works managers, foremen and forewomen, Scarborough. $24^{\text {th }}$ to $28^{\text {th }}$ April: $1-4$.

Wrong, E.M. 1920. The position of management: Probable changes. Lecture conference held at Balliol College, Oxford, April 15 th to $18^{\text {th }}$, 1920. $15^{\text {th }}$ April: 2-7.

TABLE 1

Corporate Membership of MRGs by Year, 1927-1938

\begin{tabular}{|l|l|l|l|l|l|l|l|l|l|l|l|l|}
\hline Year & 1927 & 1928 & 1929 & 1930 & 1931 & 1932 & 1933 & 1934 & 1935 & 1936 & 1937 & 1938 \\
\hline $\begin{array}{l}\text { No. of } \\
\text { Companies }\end{array}$ & 68 & 101 & 105 & 117 & 121 & 105 & 76 & 57 & 104 & 115 & 112 & 111 \\
\hline
\end{tabular}

Source: MRG annual reports.

TABLE 2

Duration of MRG Corporate Membership, 1927-1938

\begin{tabular}{|l|l|l|l|l|l|l|l|l|l|l|l|l|}
\hline $\begin{array}{l}\text { Years of } \\
\text { Membership }\end{array}$ & 1 & 2 & 3 & 4 & 5 & 6 & 7 & 8 & 9 & 10 & 11 & 12 \\
\hline $\begin{array}{l}\text { No. of } \\
\text { Companies }\end{array}$ & 18 & 23 & 53 & 67 & 13 & 14 & 9 & 13 & 8 & 4 & 7 & 14 \\
\hline
\end{tabular}

Source: MRG annual reports.

Note: The average duration of membership during this period was 4 years 9 months. However, two thirds of companies were involved in the MRG movement for 4 years or less. 
TABLE 3

\section{Data, Categories and Aggregate Themes}

\begin{tabular}{|c|c|c|}
\hline Illustrative $1^{\text {st }}$ order quotations & $\begin{array}{l}2^{\text {nd }} \text { order } \\
\text { categories }\end{array}$ & $\begin{array}{l}\text { Aggregate } \\
\text { themes }\end{array}$ \\
\hline $\begin{array}{l}\text { - }[\text { T]he whole must be cemented, not merely with the economic instinct, but } \\
\text { with the spirit of service - since industry is really a vast national service, } \\
\text { whose function is to make nature's treasures and resources of benefit to the } \\
\text { whole community (A. P. M. Fleming, 1919: 8). } \\
\text { - As administrative officers we must make it clear to the rank and file that we } \\
\text { are not out merely to increase the shareholders' dividends, but that we do } \\
\text { honestly look upon industry as human service (B. S. Rowntree, 1920: 14). }\end{array}$ & $\begin{array}{c}\text { Fulfilling a } \\
\text { national service }\end{array}$ & \multirow{2}{*}{$\begin{array}{l}\text { Business as } \\
\text { service }\end{array}$} \\
\hline $\begin{array}{l}\text { - [Y]ou may ask why democratic control industry, or industrial control by the } \\
\text { workers... should be necessary? I reply that it is rendered so by the present } \\
\text { position of the workers; and by the fact that the life of a large and important } \\
\text { section of them is virtual slavery or serfdom (D. Stewart, 1921: 34). } \\
\text { - In what degree, and in what way, is it possible to introduce the principle of } \\
\text { democracy into industry? (J. J. Mallon, 1924: 12) }\end{array}$ & $\begin{array}{l}\text { Addressing } \\
\text { industrial } \\
\text { discontent }\end{array}$ & \\
\hline $\begin{array}{l}\text { - Few [text books on management] are really adapted to the needs of the } \\
\text { practical man who wishes to get as clear an idea as possible of what modern } \\
\text { management methods mean' (Hamilton Church, 1923: 150). } \\
\text { - This close attention the study of management as a whole, although difficult, } \\
\text { was well justified by the various principles of control disclosed (MRG, 1930: } \\
\text { 14). }\end{array}$ & $\begin{array}{l}\text { Arranging } \\
\text { management } \\
\text { knowledge }\end{array}$ & \multirow{2}{*}{$\begin{array}{l}\text { Codifying } \\
\text { management } \\
\text { knowledge }\end{array}$} \\
\hline $\begin{array}{l}\text { - I think, personally, that the right type of organization for a large business is } \\
\text { what is known by 'functionalization'. This means that one man does not try } \\
\text { to perform every function in his section (B. S. Rowntree, 1920: 13). } \\
\text { - Organization is a word which everybody uses freely. It is a particularly } \\
\text { useful word, because it has no very precise meaning... We must therefore } \\
\text { define fairly closely what we mean by the word Organization (Anon., 1922: } \\
\text { 8). }\end{array}$ & $\begin{array}{l}\text { Defining key } \\
\text { terms }\end{array}$ & \\
\hline $\begin{array}{l}\text { - It is impossible to estimate the benefit we have received by meeting men } \\
\text { who are grappling in their own business with problems that are so similar to } \\
\text { our own (J. A. Crabtree, cited in MRG, 1927: 13). } \\
\text { - The co-operation of educational authorities interested in training for } \\
\text { management was felt to offer many mutual advantages (MRG, 1928: 1). }\end{array}$ & $\begin{array}{l}\text { Solving problems } \\
\text { together }\end{array}$ & \multirow[b]{2}{*}{$\begin{array}{c}\text { Emergence of } \\
\text { communities of } \\
\text { practice }\end{array}$} \\
\hline $\begin{array}{l}\text { - I have profited greatly by the information which I have picked up and by the } \\
\text { contacts which have been established (Representative of Etchells, Congdon } \\
\& \text { Muir Ltd., cited in MRG, 1927: 14). } \\
\text { - Thanks were due to many members who had collated and duplicated } \\
\text { information for the benefit of members as a whole, and who has invited } \\
\text { members to use their premises for meetings. These were signs of the very } \\
\text { real co-operation amongst Group Members' (MRG, 1937a: 3). }\end{array}$ & $\begin{array}{c}\text { Transferring } \\
\text { business } \\
\text { knowledge }\end{array}$ & \\
\hline
\end{tabular}

